INTERDISCIPLINARIA ARCHAEOLOGICA NATURAL SCIENCES IN ARCHAEOLOGY

News and views

\title{
New Radiocarbon Data for the North Bohemian Mesolithic
}

\author{
Petr Š́́da ${ }^{a^{*}}$, Jan Prostředník ${ }^{b}$, Petr Kunešc \\ aDepartment of Archaeology, Faculty of Arts, University of Hradec Králové, Rokitanského 62, 50003 Hradec Králové, Czech Republic \\ ${ }^{b}$ Museum of the Bohemian Paradise in Turnov, Skálova 71, 51101 Turnov, Czech Republic \\ 'Department of botany, Faculty of Science, Charles University in Prague, Benátská 2, 128 01, Praha 2, Czech Republic
}

\section{ARTICLE INFO}

\section{Article history}

Received: 5 December 2011

Accepted: 20 December 2011

\section{Keywords:}

Mesolithic

Northern Bohemia

${ }^{14} \mathrm{C}$ dating

\begin{abstract}
$A B S T R A C T$
Modern Czech research of Mesolithic settlements in pseudo-karst rock shelters started in 1951, with the work of F. Prošek and V. Ložek at Zátyní (Prošek, Ložek 1952). This was the first time the Mesolithic had been identified in an excavation in the Czech Republic. The material from this site has now been dated. Mesolithic settlement in the Český ráj (Bohemian Paradise) region was identified only in connection with the extensive excavations carried out by J. Svoboda $(2003 ; 2007)$. Since then the number of sites has been increasing and an important set of radiocarbon data have been obtained which complements an extensive set of radiocarbon data from the regions of Českosaské Švýcarsko and Česká Lípa.

The dataset from Český ráj includes samples from two layers of the Mesolithic settlement. The Lower Mesolithic (8300-6500 BC) was identified from six samples taken from five sites, while eight samples from three other sites were identified as Upper Mesolithic (6500-5500 BC). No Mesolithic settlement between 9300-8300 BC has yet been identified, but we assume it will be found underlying the horizons of dated samples in some sites. The most comprehensive stratigraphy, and a series of radiocarbon dates, came from a small 3 sq. m trench, at Kristova Cave, where three overlapping charcoal lenses of fireplaces were successfully dated to within a short 700 year time span (distance of two means of limiting ${ }^{14} \mathrm{C}$ values).
\end{abstract}

\section{Introduction}

Modern Czech research into Mesolithic settlement in pseudokarst rock shelters started in 1951, with the work of F. Prošek and V. Ložek at Zátyní, Czech Republic. This was one of the first mesolithic sites identified during excavations in the Czech Republic. The material from this site has now been dated. Mesolithic settlement in the Český ráj (Bohemian Paradise) region had been found in several sites, but was not identified as Mesolithic for several decades. The largest assemblages were found at the beginning of the $20^{\text {th }}$ century in Hlavatá Skála, Ludmilina Cave and Zemanova Pec, in excavations conducted by the archaeological cooperative of J. V. Šimák. Other assemblages were collected by V. Vaníček from Babí Pec and Kudrnáčova Pec in the 1930's. This was followed by the post-war excavations of F. Prošek and L. Jisl in 1947 in Babí Pec, Dvojitá Brána and other sites. These were also not identified at the time as Mesolithic. The latest

"Corresponding author. E-mail: petrsida@seznam.cz excavations with an unidentified Mesolithic layer were carried out by V. Vokolek at the Pod Pradědem rock shelter and at Hlavatá Skála in the mid-1990's.

The Mesolithic settlement in Český Ráj was only identified in connection with extensive excavations carried out by J. Svoboda (Svoboda et al. 2003; Svoboda et al. 2007). Since then, the number of sites identified as Mesolithic has been increasing steadily (Prostředník, Šída 2010). An important set of radiocarbon data has been collected which complements the extensive set from the Českosaské Švýcarsko and Česká Lípa regions (Svoboda et al. 2003).

\section{Dated Sites}

A total of 14 samples from 7 sites were dated. One came from the Česká Lípa region and six from Český Ráj, including three from the Klokočské rocks, one from Hrubá Skála and two from the area near the ruins of Trosky castle (Figure 1).

In the following list Czech names are used for sites and cadastral territories. 


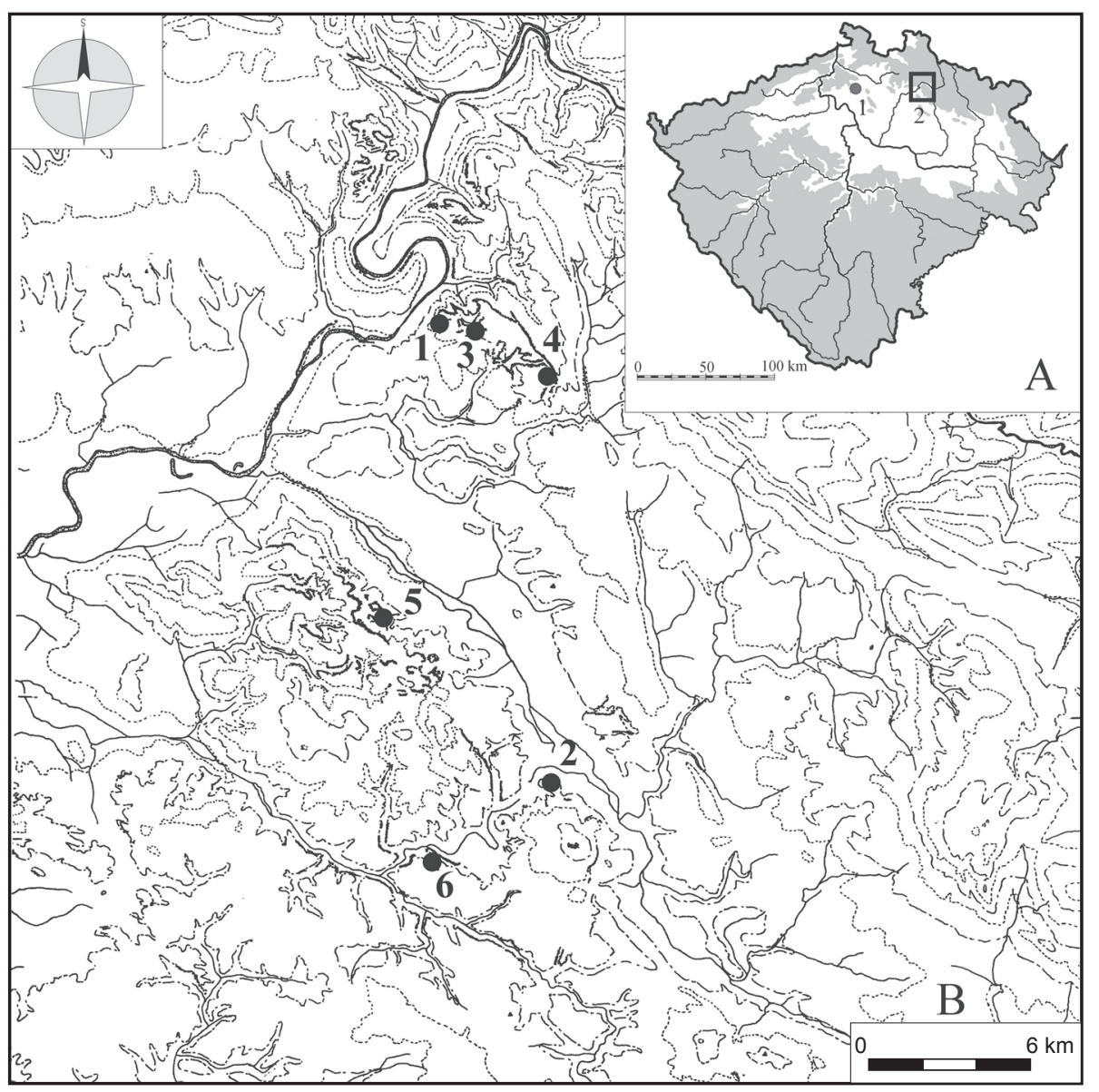

Figure 1. Dates sites. Legend: A - location of dated sites, in Bohemia; 1 - Zátyní, 2 Český ráj; $\mathrm{B}$ - Český ráj: 1 - Dvojitá brána u Rohlin, 2 - Hlavatá skála, 3 - Konejlova jeskyně, 4 - Kristova jeskyně, 5 - Abri pod Pradědem, 6 - Troskovice, převis Dr. Nastoupilové.

Dvojitá Brána u Rohlin, Bělá u Turnova cadastral territory This is a small rock gate under which the Rohliny Mesolithic site is situated. A small test pit dug in 1947 by L. Jisl and F. Prošek secured a small assemblage of Mesolithic lithics. In the spring of 2011 a follow-up excavation was made in the same pit, revealing four Mesolithic hearths at the base, in superposition, of which the middle hearth was dated (Filip 1947; Šída 2004; Prostředník, Šída 2006; Šída, Prostředník 2007; Šída, Prostředník 2010).

\section{Hlavatá skála, Hrubá Skála cadastral territory}

As early as the Lower Holocene the original rock shelter had worn down into its current shape. The first finds were uncovered at the beginning of the $20^{\text {th }}$ century. The lithic industry is apparently Mesolithic, with a portion associated with the Upper Palaeolithic tradition. The site included Funnel-beaker culture pottery, a bronze arrow from the Middle or Upper Bronze Age, and Early Modern Age pottery. In 1996 the site was excavated by V. Vokolek. In trench 1, in the southern part of the site, he identified a thick cluster of three layers with hearths, but found no artefacts. In 2005 we used charcoal from the second (middle) layer of these fireplaces to obtain the very first Mesolithic date for a site in Český Ráj (Prostředník, Šída 2006). In autumn 2010 we reopened this trench, sieved the fill, and found several dozen Mesolithic artefacts (Šída, Prostředník 2006; Filip 1947;
Šída 2004; Vokolek 1998; Prostředník, Šída 2006; Šída, Prostředník 2007; Šída, Prostředník 2010).

\section{Konejlova jeskyně, Bělá u Turnova cadastral territory}

A large rock shelter in the central part of the cuesta in the Klokočské rocks was illegally excavated and robbed by metal detectorists in 2009. Rescue excavations were conducted by J. Prostředník in 2010 and 2011. Under a remarkable La Tène settlement layer they identified a layer dated to the period of upper mesolithic to bronze age with carcoal and several artefacts. Though small test pits dug at the bottom of the main trench they identified a lower and intact Mesolithic layer. Mesolithic finds were very scarce, given the small size of the excavated area.

\section{Kristova Jeskyně, Bělá u Turnova cadastral territory}

The Museum of the Bohemian Paradise, in cooperation with the National Museum, carried out a rescue excavation in 2005 at a site that had been interfered with by a metal detector user. Under Post- medieval, La Tène and Lusatian culture layers a very thick Mesolithic layer was found. A total of 5 Mesolithic hearths and one pit were excavated in an area of $3 \mathrm{sq} . \mathrm{m}$ using modern excavation methods. Over 550 chipped lithics were found. The excavation uncovered by far the largest amount of anthracological material and macro remains in the Mesolithic of the Český ráj region. Archaeobotanical remains of fauna, 
such as bones and conches, were found together with pollen (Prostředník, Šída 2006; ك̌ída, Prostředník 2007; Šída, Prostředník 2010; Hartman, Prostředník, Šída in print 1).

\section{Abri pod Pradědem, Karlovice cadastral territory}

This rock shelter was excavated by L. Jisl and F. Prošek in 1947, and again in the 1990's by V. Vokolek. A Mesolithic layer more than $1 \mathrm{~m}$ thick, containing several hearths, was identified. Unfortunately, the excavated sediment was not sieved and only a few artefacts were found (Filip 1947; Prostředník, Vokolek 1998; Prostředník, Šída 2006; Šída, Prostředník 2007; Šída, Prostředník 2010).

Převis Dr. A. Nastoupilové, Troskovice cadastral territory This rock shelter was interfered with by an amateur excavation in 2003 (Matoušek, Jenč, Peša 2005, 89, Waldhauser, Krásný 2005, 129). A collection of 96 sherds, 3 bone fractions and a lead projectile, all uncovered as a result of the illegal excavation, were deposited with the Museum of the Bohemian Paradise in Turnov in 2005. A followup excavation, undertaken below the infill of an illegal excavation, unearthed a layer identified as a small Mesolithic settlement (Šída, Prostředník 2010; Hartman, Prostředník, Š́da in print 2).

\section{Proškův převis, Zátyní cadastral territory}

A small rock shelter near the road to Lhota near Dubá, in the Česká Lípa region was excavated in 1951 by F. Prošek and V. Ložek. They identified a Lusatian culture settlement and a Mesolithic settlement. This was the first Mesolithic archaeological excavation in the former Czechoslovakia to be supplemented by natural science research (Prošek, Ložek 1952, Matoušek, Jenč, Peša 2005).

\section{Dated samples}

The following list contains radiocarbon dated sample designation and site name.

\section{DVO01 - Dvojitá brána u Rohlin}

Carbonised piece of pine cone from hearth 2 (square A-D5A, mechanical layer 70-80 cm below surface) (Figure 2). The hearth was interfered with by F. Prošek's trench, which had been made hastily with a shovel. F. Prošek did not recognise the hearth. The group of layers and the finds were identified as Aeneolithic.

\section{HLA01 - Hlavatá skála}

A charcoal sample collected by V. Vokolek (1996) from trench 1, second hearth layer (Figure 3) (Šída, Prostředník 2006).

\section{KON01 - Konejlova jeskyně}

Charcoal sample from the deepest part of trench 4, lying at the depth of 130-140 cm (mechanical layer 14). The charcoal comes from a layer without context. Isolated chipped stone tools were found in the layer (Figure 4).

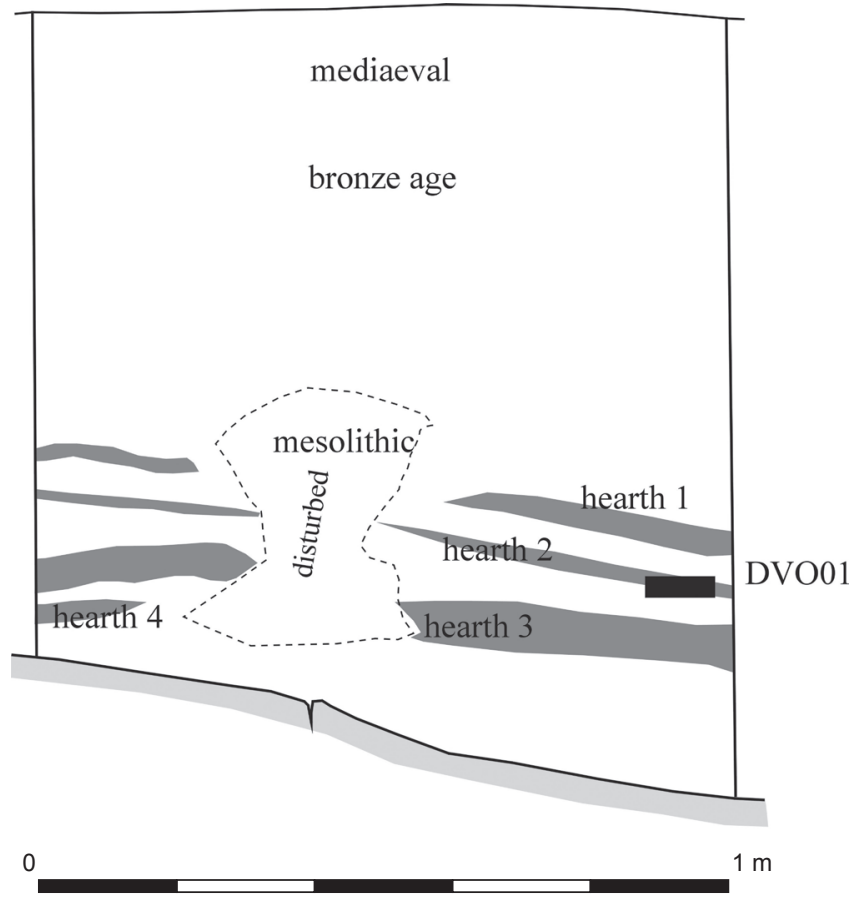

Figure 2. Dvojitá brána u Rohlin. Trench 1, eastern section. Location of dated sample.

\section{KRI01 - Kristova jeskyně}

Charcoal sample collected from Mesolithic hearth 4 (layer 14a: Figure 5).

\section{KRI02 - Kristova jeskyně}

Charcoal sample collected from Mesolithic hearth 5a (layer 20; Figure 5).

\section{KRI03 - Kristova jeskyně}

A voluminous charcoal sample collected from a larger chared piece of wood in Mesolithic hearth 5 (layer 16) was dated using the conventional method (Figure 5).

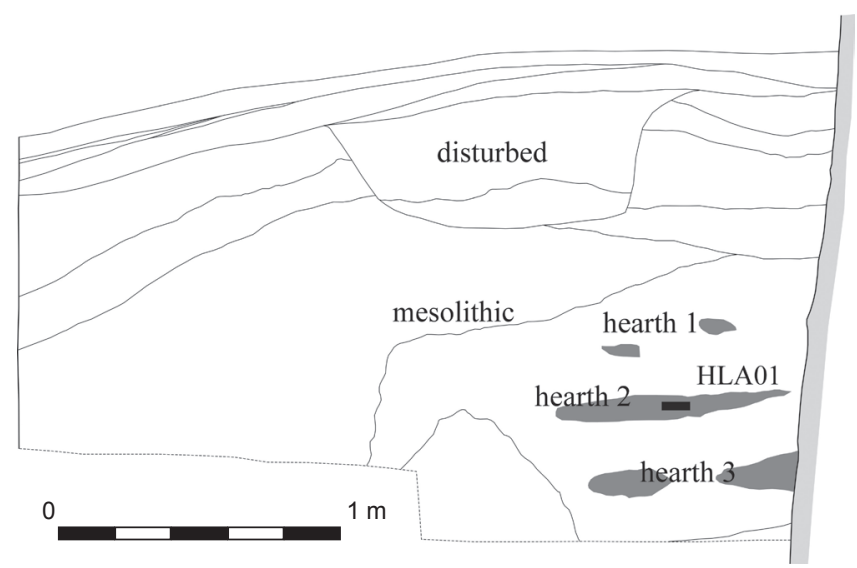

Figure 3. Hlavatá skála. Trench 1, western section. Location of dated sample. 


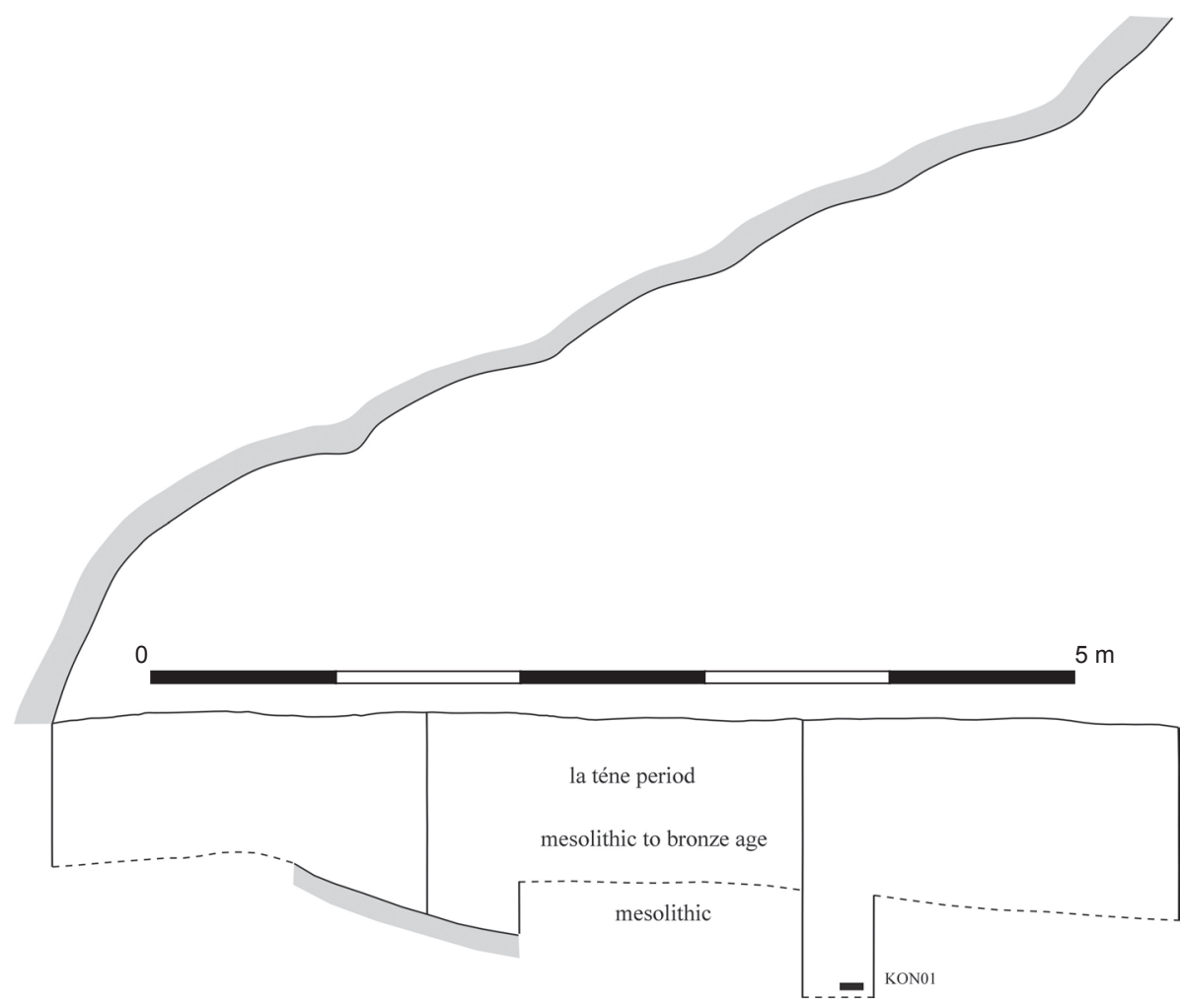

la téne period

bronze age

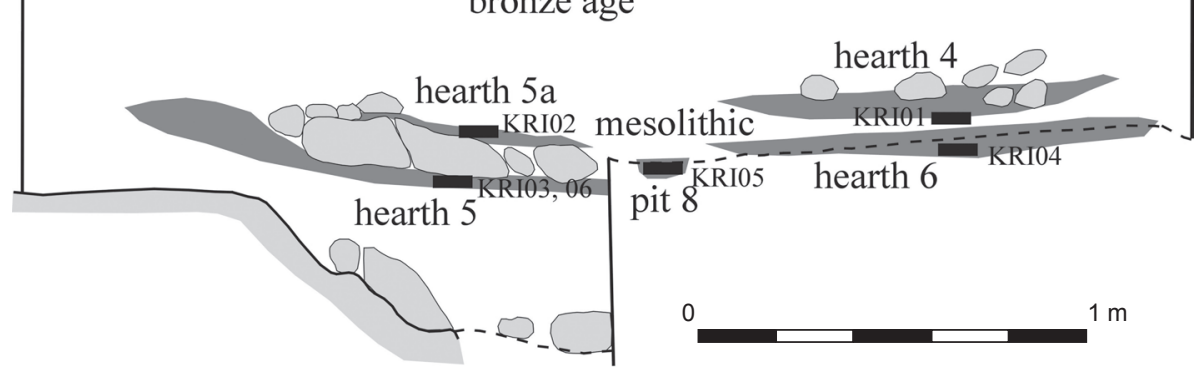

Figure 4. Konejlova jeskyně. Trenches

$2-4$. Location of dated sample.
Figure 5. Kristova jeskyně. Trench 1, northern section. Location of dated sample.

\section{KRI04 - Kristova jeskyně}

Charcoal sample collected from Mesolithic hearth 6 (layer 14b; Figure 5).

\section{KRI05 - Kristova jeskyně}

Charcoal sample collected from pit 8 (layer 25; Figure 5).

\section{KRI06 - Kristova jeskyně}

Carbonised fraction of hazelnut shell collected from Mesolithic hearth 5 (layer 16; Figure 5).

\section{PRA01 - Abri pod Pradědem}

Charcoal sample collected by V. Vokolek (1996-8) from Mesolithic hearth O. Excavation report unavailable.

\section{PRA02 - Abri pod Pradědem}

Charcoal sample collected by V. Vokolek (1996-8) from Mesolithic hearth R. Excavation report unavailable.

\section{PRA03 - Abri pod Pradědem}

Carbonised fragment of a hazelnut shell collected by V. Vokolek (1996-8) from a Mesolithic layer. Excavation report unavailable.

\section{TRO01 - Troskovice, Převis Dr. A. Nastoupilové}

Charcoal sample from the basal part of trench 1, collected at a depth of 130-140 cm (mechanical layer 14). The sample comes from a layer with no hearths or pits. The layer contained chipped stone tools (Figure 6). 


\section{ZAT01 - Zátyní, Proškův převis}

Carbonised fragment of hazelnut shell collected by F. Prošek and V. Ložek (1951) from a Mesolithic layer. Excavation report unavailable. The shells were displayed in the National Museum at the beginning of the 1960's.

\section{Chronology of the Mesolithic in Český Ráj}

The chronology of the Mesolithic in Bohemia is still not clearly settled. In line with the work of J. Svoboda (2003) we distinguish two chronological horizons - the Lower Mesolithic (9300-6500 BC) and the Upper Mesolithic (6500-5500 BC).

The dataset contains representatives of both Mesolithic settlement layers in almost equal numbers (Figure 7, Table 1). The Lower Mesolithic (9300-6500 BC) was identified with six samples from five sites while eight samples from three sites were identified as Upper Mesolithic (6500-5500 BC). No Mesolithic settlement between 9300-8300 BC have yet been identified, but we assume they will be found at new sites which have yet to be dated, such as those in the lower layer at Hlavatá Skála and at Babí Pec near Kozákov. The oldest sample comes from Konejlova Jeskyně (KON01, 8225-7945 BC). The Mesolithic layer examined here was a small 0.5 sq. $\mathrm{m}$, trench which yielded a very small assemblage of chipped stone industry but no hearths or pits. The samples from Abri pod Pradědem (PRA01, hearth $\mathrm{O}$,

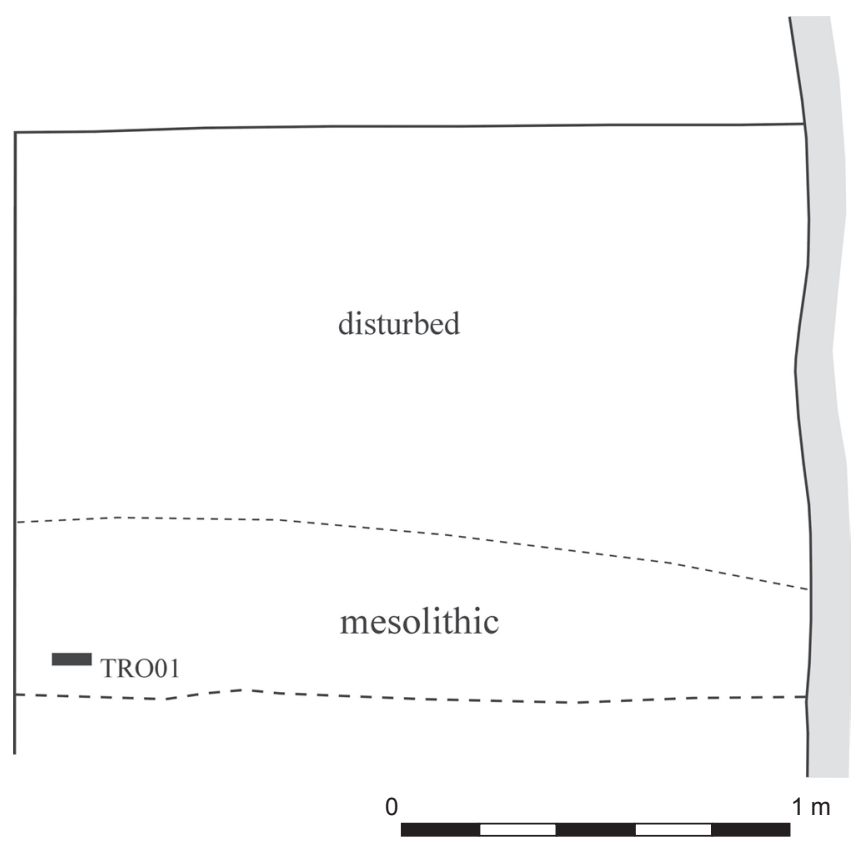

Figure 6. Troskovice, převis Dr. Nastoupilové. Trench 1, northern section. Location of dated sample.

7754-7575 BC) and Hlavatá Skála (HLA01, hearth 2, 7593$7482 \mathrm{BC}$ ) are somewhat younger. As regards age, the sample from Prošek's excavation in Zátyní (ZAT01, 7567-7330 BC) also corresponds to this layer. The settlements documented
Figure 7. Overview of radiocarbon data obtained from Český ráj and the Zátyní sample.

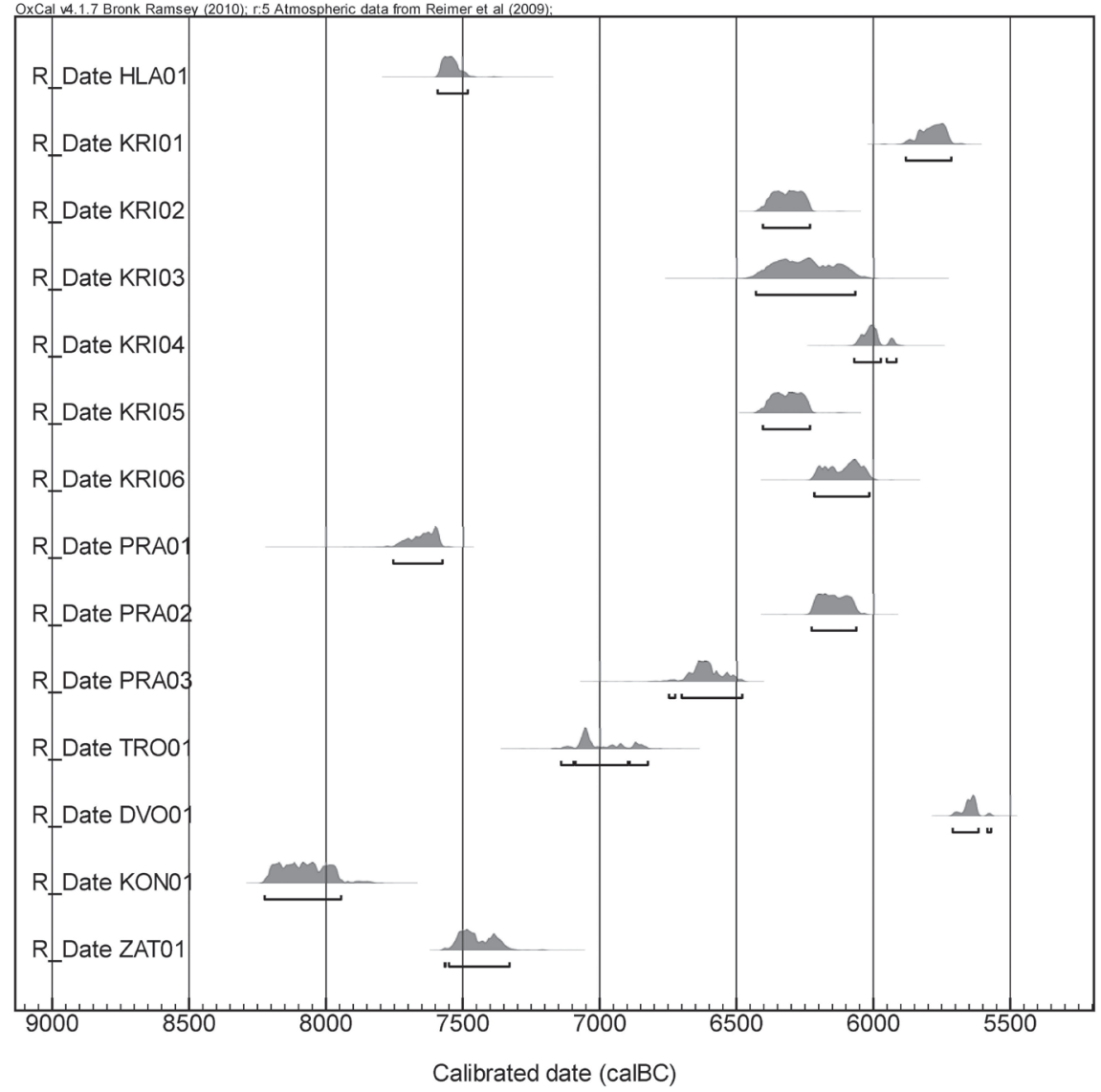


Table 1. Overview of radiocarbon dates obtained. All samples calibrated with OxCal. v. 4.1.7. (Bronk, Ramsey 2009). Atmospheric data from Reimer et al. (2009).

\begin{tabular}{|c|c|c|c|c|c|c|c|c|}
\hline$\frac{\dot{\Xi}}{\dot{\Xi}}$ & $\stackrel{0}{\mathscr{n}}$ & لِ & 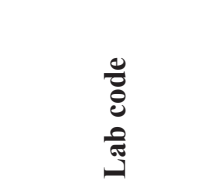 & 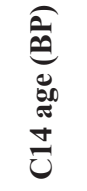 & 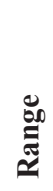 & Uై & 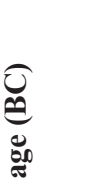 & 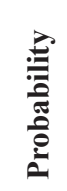 \\
\hline DVO01 & Dvojitá brána u Rohlin & fireplace 2 , layer $70-80$ & UGAMS 9516 & 6730 & 30 & 5711 & 5571 & 95.4 \\
\hline HLA01 & Hlavatá skála & fireplace 2, layer 15 & GdA-531 & 8480 & 50 & 7593 & 7482 & 95.4 \\
\hline KON01 & Konejlova jeskyně & trench 4, mechanical layer 14 & UGAMS 9512 & 8880 & 30 & 8225 & 7945 & 95.4 \\
\hline KRI01 & Kristova jeskyně 4/4/05 & fireplace 4 , layer $14 a$ & GdA-975 & 6900 & 40 & 5882 & 5716 & 95.4 \\
\hline KRI02 & Kristova jeskyně 5/20 & fireplace 5a, layer 20 & GdA-976 & 7440 & 40 & 6404 & 6232 & 95.4 \\
\hline KRI03 & Kristova jeskyně D7025 & fireplace 5, layer 16 & Crl-7025 & 7383 & 96 & 6429 & 6066 & 95.4 \\
\hline KRI04 & Kristova jeskyně 6/4/05 & fireplace 6 , layer $14 \mathrm{~b}$ & GdA-977 & 7130 & 40 & 6071 & 5916 & 95.4 \\
\hline KRI05 & Kristova jeskyně 9/8/05 & pit 8 , layer 25 & GdA-978 & 7440 & 40 & 6404 & 6232 & 95.4 \\
\hline KRI06 & Kristova jeskyně & fireplace 5, layer 16 & Poz-26089 & 7230 & 50 & 6216 & 6016 & 95.4 \\
\hline PRA01 & Abri pod Pradědem 38/97/6O & fireplace O & GdA-979 & 8630 & 50 & 7754 & 7575 & 95.4 \\
\hline PRA02 & Abri pod Pradědem 12/97/9R & fireplace $\mathrm{R}$ & GdA-980 & 7280 & 40 & 6226 & 6063 & 95.4 \\
\hline PRA03 & Abri pod Pradědem & Mesolithic layer & Poz-26088 & 7790 & 50 & 6747 & 6479 & 95.4 \\
\hline TRO01 & Troskovice & trench 1 , mechanical layer 14 & GdA-1207 & 8060 & 40 & 7141 & 6825 & 95.4 \\
\hline ZAT01 & Zátyní, Proškův převis & Mesolithic layer & Poz-26099 & 8380 & 50 & 7567 & 7330 & 95.4 \\
\hline
\end{tabular}

at Troskovice (TRO01, 7141-6825 BC) and Abri pod Pradědem (PRA03, 6747-6479 BC) are thought to be the terminal phase of the Lower Mesolithic horizon.

The Upper Mesolithic was identified in all samples from Kristova Jeskyně (KRI01 to KRI06, 6429-5716 BC). These dates correspond with the latest date found at Abri pod Pradědem (PRA02, hearth R, 6226-6063 BC). The most recent date was obtained at Dvojitá Brána u Rohlin (DVO01, 5711-5571 BC). Abri pod Pradědem is the only site to date where settlement in the Lower Mesolithic as well as the Upper Mesolithic has been confirmed. However, this site has been fully excavated, while in others only test trenches were dug.

The most comprehensive stratigraphy and radiocarbon data were obtained from a small 3 sq. $m$ trench at Kristova Jeskyně, which deserves a more detailed description (Figure 8). The most recent location in stratigraphic terms is hearth 4 , from which one sample has been dated (KRI01, 5882-5716 BC). Under hearth 4 the older hearth 6 provided one sample which has also been dated (KRI04, 6071-5916 BC). Both hearths are later than the layer with hearth 5 and pit 8 . Hearth 5 has two stages separated with positioned sandstone rocks. One sample from the upper part of the hearth above the sandstone (hearth 5a) was dated using the AMS method (KRI02, 6404$6232 \mathrm{BC}$ ). Two samples from different material types from the lower part of the hearth (hearth 5) were dated using two different methods. Sample KRI03 was collected from a large piece of carbonised wood lying in the hearth and dated using the conventional method, giving a date of 6429-6066 BC. Sample KRI06 was also collected directly from the hearth.

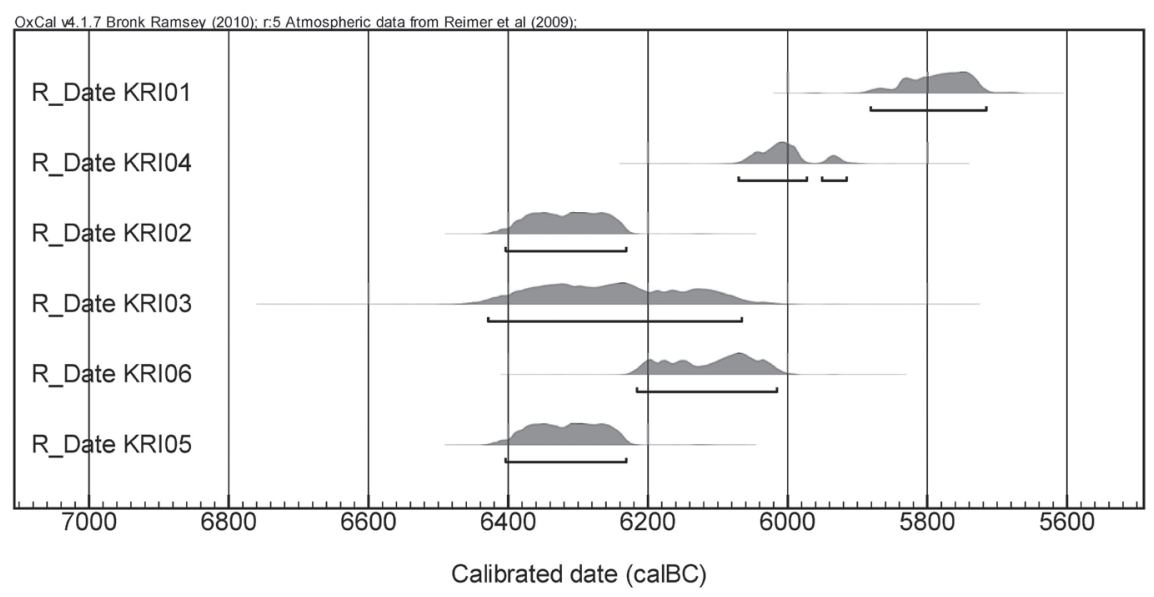

Figure 8. Kristova jeskyně. Overview of all radiocarbon data from the site. 
This sample is a carbonised hazelnut shell, which were abundant in the hearth. It was dated using the AMS method and provided a date of 6216-6016 BC. Both samples dated using the AMS method are within the interval obtained using the conventional dating method. Sample KRI01, from an upper layer, was found to be older than sample KRI06 which underlies it. This inconsistency may result from the use of different laboratories, or from the intrinsic differences in the materials dated. A short lived nutshell matures in one summer and the date obtained reflects the year it was burned in the fire. However, the carbon sample extracted from wood may provide a date that does not correspond to when it was burned. The ${ }^{14} \mathrm{C}$ content in wood is fixed shortly after lignification. If the wood came from the middle of a tree it may be hundreds of years older than the moment when it was burned.The last sample (KRI05) was taken from pit 8 at the same stratigraphy as hearth 5 . The calibrated age interval is the same as with the sample from the top layer of fireplace 5 (6404-6232 BC).

\section{Conclusion}

Research into Mesolithic settlements in the sandstone pseudokarst in Northern Bohemia has been underway for nearly 100 years. The first modern excavation was made in 1951 by F. Prošek. A consistent and long-term interest in the Mesolithic began with the excavations carried out by J. Svoboda in Heřmánky I in 1978. Since then, the team led by J. Svoboda has excavated dozens of sites in the Česká Lípa and Českosaské Švýcarsko regions (Svoboda 2003; Svoboda et al. 2007). It was a long time before the Český Ráj area became a focus of interest for researchers. Finds from this region were random and for a long time most were not recognised as Mesolithic. Recent research in Český Ráj commenced with the review excavation at Babí Pec in 2003. Since then more than twenty Mesolithic sites have been discovered, with charcoal samples obtained for radiocarbon dating from six. In addition, the sample collected by F. Prošek in Zátyní in 1951 was also dated. As with the Česká Lípa and Českosaské Švýcarsko regions, more sites tend to be dated as Lower Mesolithic (Pre-Boreal and Boreal), than Upper Mesolithic (Atlantic). Settlement in both Lower and Upper Mesolithic is confirmed at only one site.

In recent years the number of radiocarbon dates has significantly increased. What is important is that it is possible to date event-related artefacts (hearths) by means of short- lived plant parts, such as macro remains (seeds, cones and twigs). This helps to increase the quantity of precisely dated layers which enable us to establish a chronology for the chipped lithic industry in the Czech Mesolithic.

Translation by H. Zlatnik. Copy edit and language correction by R. Brukner.

\section{References}

FILIP J. 1947: Dějinné počátky Českého ráje. Praha.

BRONK RAMSEY, C. 2009: Bayesian analysis of radiocarbon dates. Radiocarbon 51 (1), 337-360.

HARTMAN, P., PROSTŘEDNÍK, J., ŠÍDA, P. in print 1: Záchranný archeologický výzkum Kristovy jeskyně v Klokočských skalách, Piskovcový fenomén.

HARTMAN, P., PROSTŘEDNÍK, J., ŠÍDA, P. in print 2: Záchranný archeologický výzkum převisu na břehu Věžáku, Pískovcový fenomén.

MATOUŠEK, V., JENČ, P., PEŠA, V. 2005: Jeskyně Čech, Moravy a Slezska $s$ archeologickými nálezy. Praha.

PROSTŘEDNÍK, J., ŠÍDA, P. 2006: Mezolitické osídlení pseudokrasových skalních dutin v Českém ráji. In: Sborník z konference 50. let CHKO Český Ráj, Z Českého ráje a Podkrkonoši - supplementum 11, 83-106.

PROSTŘEDNÍK, J., ŠIIDA, P. 2010: Nejstarši dějiny Českého ráje a horního Pojizeři. Turnov.

PROSTŘEDNÍK, J., VOKOLEK, V. 1998: Archeologický výzkum skalních lokalit Českého ráje v letech 1994 - 1997, Z Českého ráje a Podkrkonoši 11, 119-132.

PROŠEK, F., LOŽEK, V. 1952: Mesolitické sídliště v Zátyní u Dubé, Anthropozoikum 2, 93-115.

REIMER, P. J. et al. 2009: IntCal09 and Marine09 radiocarbon age calibration curves, 0-50,000 years cal BP, Radiocarbon 51 (4), 11111150 .

SVOBODA, J. A. (Ed.) 2003: Mezolit severnich Čech. Komplexní výzkum skalních převisů na Českolipsku a Déčinsku 1978-2003. Dolnověstonické studie 9. Brno.

SVOBODA, J. A. et al. 2007: Mesolithic Settlement and Activities in Rock Shelters of the Kamenice River Canyon, Czech Republic, Eurasian Prehistory 5 (1): 95-127.

ŠÍDA, P. 2004: Neolitická a eneolitická kamenná industrie v oblasti horního Pojizeří. In: Lutovský, M. (Ed.): Otázky neolitu a eneolitu našich zemí2003, 377-408

ŠÍDA, P., PROSTŘEDNÍK, J. 2006: Mezolit pod Hlavatou skálou v Českém ráji (k. ú. Hrubá Skála, okr. Semily). In: Vencl, S, Sigl, J., Sedláček, R. (Eds.): Vita Archaeologica, Hradec Králové - Pardubice, 207-228.

ŠÍDA, P., PROSTŘEDNÍK, J. 2007: Mezolit a pozdní paleolit Českého ráje: perspektivy poznání regionu, Archeologické rozhledy LIX, 443-460.

ŠÍDA, P., PROSTŘEDNÍK, J. 2010: Předneolitické osídlení pseudokrasu Českého ráje. In: Krištuf, P., Vařeka, P. (Eds.): Opomíjená archeologie 2007-2008, 112-129.

VOKOLEK, V. 1998: Eneolitické nálezy u „Hlavaté skály“, k. ú. Hrubá skála. In: Prostředník, J., Vokolek, V. (Eds.): Otázky neolitu a eneolitu našich zemí. Turnov - Hradec Králové, 113-122.

WALDHAUSER, J., KRÁSNÝ, F. 2005: Problémy konce doby laténské v Pojizeří. In: Archeologie barbarů 2005. Praha, 91-153. 
